\title{
The influence of the bulk density of the coal blend on the gross calorific value of blast furnace coke
}

\author{
$\underline{\text { Denis Miroshnichenko }^{1}}$, Igor Miroshnichenko ${ }^{2}$ \\ 1. Department of technology of oil refining, gas and solid fuel, National Technical University \\ "Kharkiv Polytechnic Institute", Ukraine, Kharkiv, st. Kirpichov, 2, e-mail: dvmir79@gmail.com \\ 2. Department of technology of oil refining, gas and solid fuel, National Technical University \\ "Kharkiv Polytechnic Institute", Ukraine, Kharkiv, st. Kirpichova, 2, e-mail: \\ igor.miroshnichenko@metinvestholding.com
}

Abstract - it has been established that increasing the bulk density of the coal blend from 0.8 to $1.15 \mathrm{~g} / \mathrm{cm}^{3}$ leads to an increase in the gross calorific value of blast-furnace coke by 0.05 $0.12 \mathrm{MJ} / \mathrm{kg}$.

Keywords - coal, analysis, bulk density, coke, gross calorific value,

\section{Introduction}

In work [1] it is noted that the prospects for the development of ferrous metallurgy and the influence that the need for saving energy resources and reducing carbon dioxide emissions have on it depends largely on the technological processes in the production of pig iron and coke. In conditions of limited coking coal resources and increasingly tough environmental legislation, coke and pig iron producers in recent years have joined forces to improve coking technology based on technical requirements for the quality and properties of coke in a blast furnace. About $70 \%$ of all energy costs in the iron and steel industry are accounted for by energy consumption in the iron production system, including about $50 \%$ in blast furnaces, about $15 \%$ in coke production, about $5 \%$ in sinter production and about $1 \%$ in production pellets [2]. This indicates the fact that the production of pig iron has the greatest potential for energy saving in the iron and steel industry, and the processes in blast furnaces and in coke production are characterized by the greatest energy intensity and carbon consumption [3]. In turn, about 55-65\% of the mass of coke burns as fuel in the circulation zone in front of the tuyeres, which indicates the need to increase the carbon content in coke and its heat of combustion.

It is known that the quality of the coal blend and, in particular, its bulk density $[4,5]$, have a great influence on the quality of the blast furnace coke.

\section{Results}

To determine the effect of the bulk density of the coal charge on the value of the gross calorific value obtained from its coke, special studies were conducted.

Four coal blends were compiled, characterized by a different set of quality indicators. Table 1 shows the indicators of their proximate, petrographic and ultimate analyzes, from which it can be seen that they significantly differ in these indicators.

Table 1

Technological properties of the experimental blends

\begin{tabular}{|c|c|c|c|c|c|c|c|c|}
\hline \multirow{2}{*}{ Blend } & \multicolumn{4}{|c|}{ Proximate and petrographic analysis, \% } & \multicolumn{5}{|c|}{ Ultimate analysis, \% } \\
\cline { 2 - 9 } & $\mathrm{A}^{\mathrm{d}}$ & $\mathrm{V}^{\text {daf }}$ & $\mathrm{R}_{\mathrm{o}}$ & $\mathrm{C}^{\text {daf }}$ & $\mathrm{H}^{\text {daf }}$ & $\mathrm{N}^{\text {daf }}$ & $\mathrm{S}_{\mathrm{t}}{ }^{\mathrm{d}}$ & $\mathrm{O}_{\mathrm{d}}{ }^{\text {daf }}$ \\
\hline 1 & 8.3 & 27.1 & 1.06 & 85.43 & 4.84 & 2.14 & 0.54 & 7.05 \\
\hline 2 & 8.5 & 29.0 & 0.96 & 84.60 & 4.93 & 2.17 & 0.53 & 7.77 \\
\hline 3 & 8.2 & 31.7 & 0.98 & 83.69 & 5.05 & 2.20 & 0.50 & 8.56 \\
\hline 4 & 8.5 & 33.2 & 0.84 & 82.96 & 5.11 & 2.26 & 0.47 & 9.20 \\
\hline
\end{tabular}


The mixtures were detailed to a content of $100 \%$ class $0-3 \mathrm{~mm}$, compacted to a density of 0.8 and $1.15 \mathrm{~g} / \mathrm{cm}^{3}$, and coked in a $5-\mathrm{kg}$ laboratory furnace. The results of the determination of proximate and calorimetric analyzes of the obtained coke are shown in table 2 .

Table 2

Technological properties and gross calorific value of experimental coke

\begin{tabular}{|c|c|c|c|c|}
\hline \multirow[t]{2}{*}{ Blend } & \multirow{2}{*}{$\begin{array}{l}\text { Bulk density of } \\
\text { coal blend, } \\
\mathrm{g} / \mathrm{cm}^{3}\end{array}$} & \multicolumn{2}{|c|}{$\begin{array}{l}\text { Proximate } \\
\text { analysis, \% }\end{array}$} & \multirow{2}{*}{$\begin{array}{c}\begin{array}{c}\text { Gross calorific } \\
\text { value, } \mathrm{MJ} / \mathrm{kg}\end{array} \\
\mathrm{Q}_{\mathrm{s}}^{\text {daf }}\end{array}$} \\
\hline & & $A^{d}$ & $\mathrm{~V}^{\text {daf }}$ & \\
\hline \multirow{2}{*}{1} & 0.8 & 11.7 & 0.5 & 32.56 \\
\hline & 1.15 & 10.9 & 0.5 & 32.61 \\
\hline \multirow{2}{*}{2} & 0.8 & 11.6 & 0.5 & 32.80 \\
\hline & 1.15 & 12.0 & 0.7 & 32.92 \\
\hline \multirow{2}{*}{3} & 0.8 & 11.2 & 0.5 & 32.88 \\
\hline & 1.15 & 11.6 & 0.7 & 32.93 \\
\hline \multirow{2}{*}{4} & 0.8 & 12.0 & 0.7 & 32.79 \\
\hline & 1.15 & 12.2 & 0.6 & 32.87 \\
\hline
\end{tabular}

\section{Conclusion}

Based on the conducted research, it can be concluded that compaction of the coal blend from 0.8 to $1.15 \mathrm{~g} / \mathrm{cm}^{3}$ using coal blends differing in proximate, petrographic and ultimate analyzes results in an increase in the gross calorific value of blast-furnace coke by $0.05-0.12 \mathrm{MJ} / \mathrm{kg}$.

\section{References}

[1] Kejiang Li, Mansoor B., Jianliang Z. et al. "Advanced coke quality characterization and cokemaking techniques based on in depth understanding of coke behavior inside blast furnace”, AIS Tech. Pittsburgh, Pennsylvania, USA, 2016, pp. 273-283.

[2] Guo Z., Fu Z. "Current situation of energy consumption and measures taken for energy saving in the iron and steel industry in China”, Energy, vol. 35, pp. 4356-4360, 2010.

[3] Zhaug K.Li., Liu Z., Waug T., Ning X., Zhoug J., Xu R., Wang G., Ren S., Yang T. "Zinc accumulation and behavior in Tuyere coke", Metallurgical and materials Transactions, vol. 45, pp. 1581-1588, 2014.

[4] Miroshnichenko D.V. "Influence of coal preparation and coking conditions on coke reactivity", Coke and Chemistry, vol. 52, no. 2, pp. 77-82, 2009.

[5] Shmeltser E.O., Lyalyuk V.P., Sokolova V.P., Miroshnichenko D.V. "The using of coal blends with an increased content of coals of the middle stage of metamorphism for the production of the blast furnace coke. Message 1. Preparation of coal blends", Petroleum and coal, vol. 60, no. 4, pp. 605-611, 2018. 